\section{Phenotypical variability of post-partum reversible cerebral vasoconstriction syndrome}

\author{
Benjamin Matosevic,' Martin Furtner, ${ }^{1}$ \\ Michael Knoflach,' Christoph Schmidauer, \\ Georg Wille,' Thaddaeus Gotwald, \\ Stefan Kiechl,' Johann Willeit' \\ 'Department of Neurology and \\ 2Department of Diagnostic Radiology, \\ Medical University of Innsbruck, Austria
}

\section{Abstract}

Reversible cerebral vasoconstriction syndrome is recognized increasingly as a complication of the postpartum period. Our series of four cases illustrates its phenotypical variability, summarizes the diagnostic work-up, and outlines potential treatment strategies for this usually benign but sometimes disabling and life-threatening disease.

\section{Introduction}

Reversible cerebral vasoconstriction syndrome (RCVS) is an under-recognized condition of the puerperium. ${ }^{1}$ Formerly known as benign angiopathy of the central nervous system, its clinical course has been described to be more malignant occasionally than this name suggests. We discuss four cases of postpartum RCVS and present one illustrative and severe case in detail. The other three cases are summarized in Table 1.

\section{Case Report}

In April 2006, five days after an uncomplicated pregnancy and childbirth, a healthy 40-yearold woman developed sudden, severe, and persisting headache. On day 1 postpartum she had been given a single dose of cabergoline $(0.5$ $\mathrm{mg}$ ) for ablactation. Cerebral computed tomography (CCT), magnetic resonance imaging (MRI), electroencephalography (EEG), and lumbar puncture at a primary hospital showed no abnormalities. On day 7 postpartum she suffered a generalized seizure with head trauma from a fall. The CCT demonstrated a cortical, frontoparietal, superfical subarachnoid hemorrhage (SAH), which was located beneath a skin bruise; hence the SAH was considered traumatic.

On admission to the stroke unit she complained of headache, responded slowly to ques- tions, and had elevated blood pressure (200/100 $\mathrm{mmHg})$, right peripheral visual deficits, and extensor pyramidal signs on the right side. The MRI revealed bilateral occipitoparietal vasogenic edema without evidence of sinus venous thrombosis (SVT) or arterial abnormalities (Figure 1). Transcranial Doppler ultrasound (TCD) showed normal flow velocities with no evidence of vasospasm. Antihypertensive therapy with intravenous (i.v.) urapidil was initiated. However, she complained further of double vision, developed severe right-sided hemiparesis, and became aphasic. Serial MRT scans showed segmental, rapidly progressive arterial narrowing of all cerebral vessels (Figure 1). Hence, nimodipin i.v. $(1 \mathrm{mg} / \mathrm{h})$ in combination with triple-H therapy (hypertension, hypervolemia, hemodilution) was started. However, multiple ischemic strokes and spreading of vasogenic edema emerged (Figure 1). Serum markers for connective tissue diseases, systemic vasculitis, urine catecholamines, and investigation of cerebrospinal fluid, biochemical testing for porphyrias, as well as transthoracic echocardiography were unremarkable. Because of progressive generalized vasospasm, i.v. methylprednisolon at a dosage of $1000 \mathrm{mg}$ daily over five days was added, with dose tapering to 80 mg orally until discharge. Under this treat-
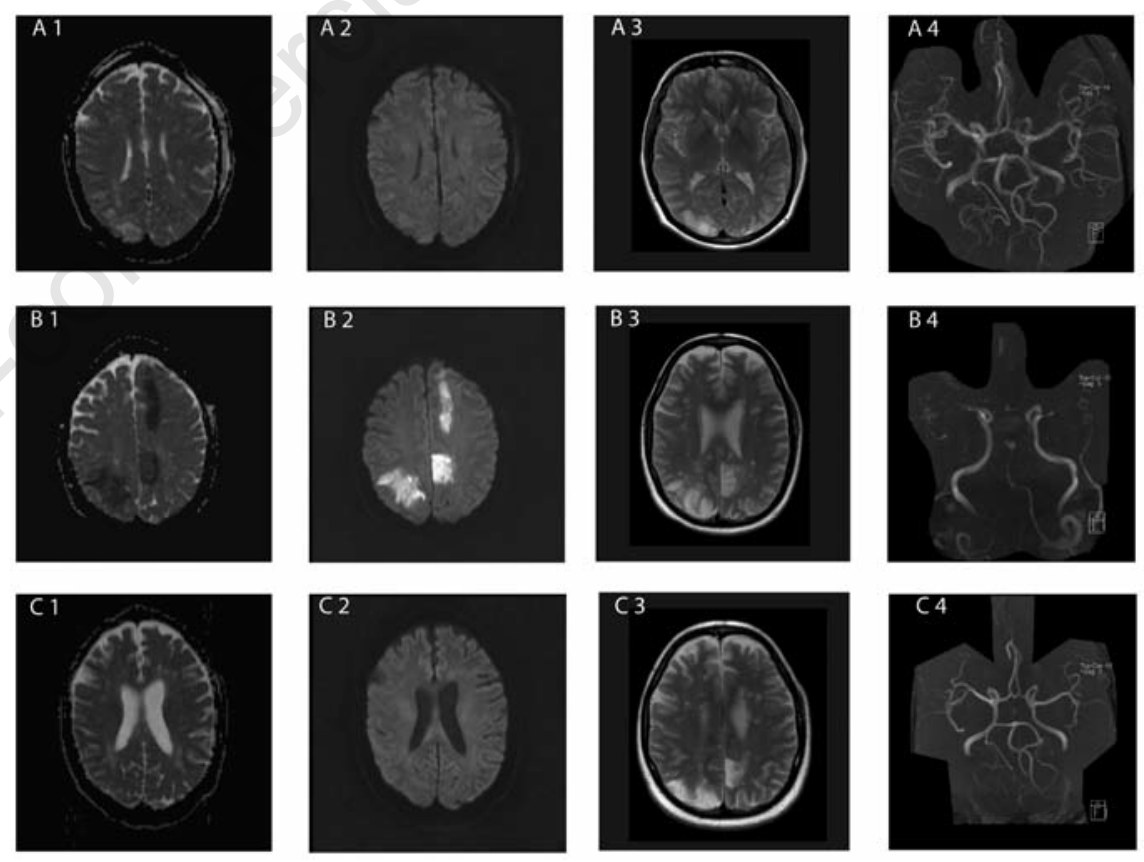

Figure 1. A1-A4: magnetic resonance (MR) images on admission of patient \#1, showing hyperintensities (vasogenic edema) on ADC (apparent diffusion coefficient; A1), DWI (diffusion weighted imaging; A2) and T2-weighted (A3) images, accentuated in the right occipital pole. There were no vessel abnormalities on TOF-MRA (time of flight magnetic resonance angiography; A4). B1-B4: 10 days later, MR images show multiple ADC hypointensities (B1) and DWI hyperintensities (B2) on corresponding levels, typical for infarction. Vasogenic edema is still evident on T2-weighted images (B3). TOF-MRA (B4) reveals severe and multiple vasoconstriction. C1-C4: follow-up MR images after four months show no abnormalities in ADC (C1) and DWI (C2) maps. On T2-weighted images (C3), old cerebral infarctions are evident. TOF-MRA (C4) demonstrates complete resolution of cerebral vasoconstriction. 
Table 1. Summary of all four cases.

\begin{tabular}{|c|c|c|c|c|c|c|c|c|c|c|}
\hline $\begin{array}{l}\text { Patient } \\
\text { No. }\end{array}$ & $\begin{array}{l}\text { Age } \\
\text { (years) }\end{array}$ & $\begin{array}{l}\text { Onset } \\
\text { postpartum } \\
\text { (days) }\end{array}$ & $\begin{array}{l}\text { Medication } \\
\text { prior to } \\
\text { onset }\end{array}$ & $\begin{array}{l}\text { Presenting } \\
\text { features }\end{array}$ & $\begin{array}{l}\text { Imaging } \\
\text { findings } \\
\text { (MR, CT, } \\
\text { TCD, DSA) }\end{array}$ & $\begin{array}{l}\text { Laboratory and } \\
\text { CSF examinations }\end{array}$ & $\begin{array}{l}\text { Initial clinical } \\
\text { presentation }\end{array}$ & $\begin{array}{l}\text { Clinical } \\
\text { course }\end{array}$ & Treatment & Follow-up \\
\hline $1^{*}$ & 40 & 5 & Cabergoline & $\begin{array}{l}\text { Headache, } \\
\text { generalized } \\
\text { seizure, } \\
\text { arterial } \\
\text { hypertension } \\
\text { (RR 200/100) }\end{array}$ & $\begin{array}{l}\text { MR: } \\
\text { vasoconstriction, } \\
\text { DWI lesions, } \\
\text { SAH, reversible } \\
\text { posterior } \\
\text { leukoencephalopathy } \\
\text { TCD: elevated } \\
\text { blood flow }\end{array}$ & Normal & $\begin{array}{l}\text { Psychomotor } \\
\text { slowing, } \\
\text { dysarthria, } \\
\text { partial } \\
\text { hemianopsia }\end{array}$ & $\begin{array}{l}\text { Right-sided } \\
\text { hemiparesis, } \\
\text { aphasia, } \\
\text { blurred } \\
\text { and double } \\
\text { vision }\end{array}$ & $\begin{array}{l}\text { i.v. nimodipin, } \\
\text { corticoids, } \\
\text { hydroxy-ethyl } \\
\text { starch, } \\
\text { urapidil }\end{array}$ & $\begin{array}{l}4 \text { months: } \\
\text { slight } \\
\text { right-sided } \\
\text { hemiparesis, } \\
\text { complete } \\
\text { resolution of } \\
\text { vasoconstriction } \\
\text { on MRA }\end{array}$ \\
\hline 2 & 33 & 4 & $\begin{array}{l}\text { Magnesium, } \\
\text { dihydralazin }\end{array}$ & $\begin{array}{l}\text { Generalized } \\
\text { seizure, } \\
\text { arterial } \\
\text { hypertension } \\
\text { (RR 170/100) }\end{array}$ & $\begin{array}{l}\text { MR: reversible } \\
\text { posterior } \\
\text { leukoencephalopathy, } \\
\text { vasoconstriction } \\
\text { TCD: vasospasm }\end{array}$ & $\begin{array}{l}\text { Platelets } 69 \\
\text { G/L, G0T } 56 \mathrm{U} / \mathrm{L} \text {, } \\
\text { GPT } 91 \mathrm{U} / \mathrm{L} \text {, } \\
\text { gamma-GT } 29 \mathrm{U} / \mathrm{L} \text {, } \\
\text { LDH } 454 \mathrm{U} / \mathrm{L} \\
\text { urine protein } \\
5000 \mathrm{mg} / \mathrm{dL}\end{array}$ & No focal deficits & $\begin{array}{l}\text { Asymptomatic } \\
\text { dissection } \\
\text { of left ICA, } \\
\text { complete } \\
\text { resolution } \\
\text { of vasospasm } \\
\text { after } 10 \text { days }\end{array}$ & $\begin{array}{l}\text { i.v. nimodipin } \\
\text { magnesium } \\
\text { dihydralazin }\end{array}$ & $\begin{array}{l}4 \text { months: } \\
\text { no further } \\
\text { symptoms, } \\
\text { normal } \\
\text { vessel } \\
\text { status } \\
\text { on MRA }\end{array}$ \\
\hline 3 & 33 & 6 & Bromocriptine & $\begin{array}{l}\text { Headache, } \\
\text { generalized } \\
\text { seizure, } \\
\text { arterial } \\
\text { hypertension } \\
\text { (RR 170/90) }\end{array}$ & $\begin{array}{l}\text { MR: reversible } \\
\text { posterior } \\
\text { leukoencephalopathy, } \\
\text { vasogenic edema, } \\
\text { hemorrhagic changes } \\
\text { DSA: } \\
\text { vasoconstriction }\end{array}$ & Normal & cits & $\begin{array}{l}\text { Benign } \\
\text { clinical } \\
\text { course, } \\
\text { complete } \\
\text { resolution } \\
14 \text { days } \\
\text { after initial } \\
\text { symptoms }\end{array}$ & $\begin{array}{l}\text { Oral } \\
\text { nimodipin, } \\
\text { corticoids, } \\
\text { urapidil, } \\
\text { phenytoin }\end{array}$ & $\begin{array}{l}\text { one year: } \\
\text { no recurring } \\
\text { events, } \\
\text { normal } \\
\text { vessel } \\
\text { status } \\
\text { on MRA }\end{array}$ \\
\hline 4 & 34 & 4 & $\begin{array}{l}\text { No } \\
\text { vasoactive } \\
\text { medication }\end{array}$ & $\begin{array}{l}\text { Headache, } \\
\text { generalized } \\
\text { seizure }\end{array}$ & $\begin{array}{l}\text { MR: reversible } \\
\text { posterior } \\
\text { leukoencephalopathy, } \\
\text { vasoconstriction, } \\
\text { SVT } \\
\text { TCD: elevated } \\
\text { blood flow }\end{array}$ & Normal & $\begin{array}{l}\text { Headache, } \\
\text { blurred vision, } \\
\text { diplopia }\end{array}$ & $\begin{array}{l}\text { Benign } \\
\text { clinical } \\
\text { course, } \\
\text { normal } \\
\text { vessels } \\
\text { on MRA } \\
11 \text { days after } \\
\text { onset }\end{array}$ & $\begin{array}{l}\text { Oral } \\
\text { anticoagulation } \\
\text { for SVT, } \\
\text { clobazam }\end{array}$ & $\begin{array}{l}\text { One year: } \\
\text { no further } \\
\text { clinical } \\
\text { symptoms, } \\
\text { normal } \\
\text { vessel } \\
\text { status on } \\
\text { MRA }\end{array}$ \\
\hline
\end{tabular}

*Illustrative case vignette; MR, magnetic resonance; CT, computed tomography; TCD, transcranial Doppler sonography; DSA, digital subtraction angiography; CSF, cerebrospinal fluid; RR, blood pressure in mmHg; DWI, diffusion-weighted imaging; SAH, subarachnoid hemorrhage; SVT, sinus venous thrombosis; ICA, internal carotid artery; MRA, magnetic resonance angiography; i.v., intravenous.

ment, the patient stabilized and improved substantially. In line with this, the MRI showed rapid regression of vasoconstriction and vasogenic edema, and shrinking of DWI (diffusion weighted imaging) lesions (Figure 2). She was transferred to a rehabilitation center for physical therapy and speech therapy. At a follow-up visit three months later, the aphasia had completely recovered and only a slight non-disabling paresis of the right leg persisted.

\section{Discussion}

Thunderclap headache, seizures, and occasionally visual or sensorimotor ${ }^{2}$ deficits in combination with normal cerebrospinal fluid (CSF) and segmental arterial vasoconstriction are typical for RCVS. ${ }^{1}$ Reversibility of vasoconstriction within two months and absence of vasculitis further support this diagnosis ${ }^{3,4}$ Our illustrative postpartum case presented with all of these clinical features, whereas the other three patients suffered from headache, visual disturbances, and seizures (Table 1). In line
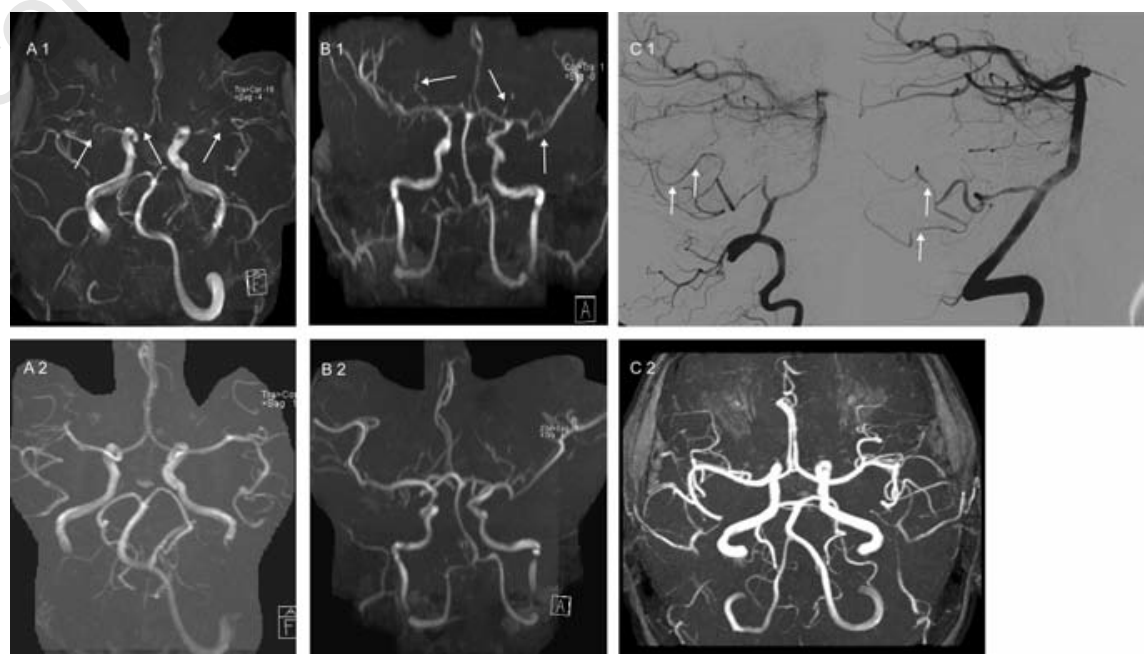

Figure 2. (A1 and A2) Cerebral magnetic resonance angiograms of patient \#2 showing multisegmental vasoconstriction (white arrows, A1). Magnetic resonance angiography four months later (white arrows, A2) reveals normal vessel status. (B1 and B2) Magnetic resonance angiography of patient \#4 reveals multisegmental vessel narrowing (white arrows, B1). One year later (white arrows, B2) no vessel abnormality is evident. (C1 and C2) Digital subtraction angiography demonstrates segmental narrowing of vessels, predominantly in both posterior inferior cerebellar arteries (white arrows, $\mathrm{C1}$ ). Follow-up magnetic resonance angiography one year later shows normal vessel status (white arrows, C2). 
with the literature, the outcome of our patients was excellent in three and good in one with mild residual deficits. However, severe disabling strokes, $\mathrm{SAH}$, and even death have been reported. ${ }^{2,3,5-7}$ Because of a seizure-related fall, the superficial SAH in our leading case was considered as traumatic, but a vasospasmmediated SAH is as likely. Lacking a CT scan immediately before the seizure, we are not able to discern if seizure induced the SAH or vice versa. An aneurysmal origin of the SAH can be excluded by its minor size and superficial localization.

The common feature of all four postpartum cases was seizures, occurring early in the disease, which is a well-known complication in RCVS. $^{3,7}$ Interestingly, the phenomenology of symptoms apart from seizures was quite different. In two patients, there were no focal deficits. In these cases, the vascular pathology and parenchymal edema seen on central nervous system (CNS) imaging was less widespread than in the other two, probably indicating less exposure to a putative endothelialnoxious factor. However, we were not able to elicit predisposing factors from the history or from laboratory findings. Two cases exhibited unusual features; in one case, there was internal carotid artery (ICA) dissection, which may have been a result of mechanical strain from the initial generalized seizure. In another case, there was SVT remote from the area of vasoconstriction and vasogenic edema. Because SVT is a common complication of the peripartum period, this may have been a chance coincidence. However, it is tempting to speculate on a generalized vulnerability of the cerebral vasculature in both cases.

The pathophysiology of RCVS remains unclear. There are predisposing conditions like eclampsia or vasoactive drug intake; ${ }^{3,8}$ as in eclampsia, imbalances between the proangiogenic placental growth factor (PIGF) and the antiangiogenic soluble PIGF receptor (sFlt1) are assumed to cause postpartum RCVS. ${ }^{7}$ In this setting, ergoline medication (e.g. for ablactation) might facilitate vasoconstriction. ${ }^{2,5}$ In our cases, as in the literature, there is a broad overlap of eclampsia, hemolytic an- emia/elevated liver enzymes/low platelets (HELLP)-syndrome, cerebral sinus thrombosis, and cervical artery dissection. ${ }^{9}$ Hyper tension-induced endothelial dysfunction may be the common cause for vasogenic edema, thrombosis, or dissection through a cascade of vessel wall injury and endothelin-mediated vasoconstriction.

The most important differential diagnosis to RCVS is primary angiitis of the CNS (PACNS). However, PACNS is more prevalent in men than in women and has a median age range of 40 to 60 years. Moreover, the onset of symptoms is often insidious and CSF examination may demonstrate leukocytosis and elevated protein levels. ${ }^{10}$ As all this was absent in our patients, the diagnosis of PACNS was discarded. In addition, CNS imaging did not support a diagnosis of angiitis.

For treatment, most centers use oral, intravenous, or occasionally intra-arterial nimodipin. $^{11,12}$ In our case vignette and in earlier reports, i.v. steroids were effective in patients nonresponsive to nimodipin, with a rapidly progressive, vasculitis-like course. ${ }^{13,14}$ In the absence of treatment guidelines for RCVS, therapeutic decisions have to be tailored for each patient and their efficacy needs to be constantly checked by clinical examination and imaging controls. Awareness of RCVS and its speedy recognition are crucial. Otherwise, gradual progression of vasoconstriction and serious complications, such as ischemic infarction, may ensue.

\section{References}

1. Call GK, Fleming MC, Sealfon S, et al. Reversible cerebral segmental vasoconstriction. Stroke 1988;19:1159-70.

2. Ducros A, Boukobza M, Porcher R, et al. The clinical and radiological spectrum of reversible cerebral vasoconstriction syndrome. A prospective series of 67 patients. Brain 2007;130:3091-101.

3. Calabrese LH, Dodick DW, Schwedt TJ, et al. Narrative review: reversible cerebral vasoconstriction syndromes. Ann Intern Med 2007;146:34-44.

4. The International Classification of Headache Disorders: 2nd edn. Cephalalgia 2004;24(Suppl 1):9-160.

5. Fletcher JJ, Kramer AH, Bleck TP, et al. Overlapping features of eclampsia and postpartum angiopathy. Neurocrit Care 2009;11:199-209.

6. Geraghty JJ, Hoch DB, Robert ME, et al. Fatal puerperal cerebral vasospasm and stroke in a young woman. Neurology 1991;41:1145-7.

7. Singhal AB, Kimberly WT, Schaefer PW, et al. Case records of the Massachusetts General Hospital. Case 8-2009. A 36-yearold woman with headache, hypertension, and seizure 2 weeks post partum. N Engl J Med 2009;360:1126-37.

8. Henry PY, Larre P, Aupy M, et al. Reversible cerebral arteriopathy associated with the administration of ergot derivatives. Cephalalgia 1984;4:171-8.

9. Arnold M, Camus-Jacqmin M, Stapf C, et al. Postpartum cervicocephalic artery dissection. Stroke 2008;39:2377-9.

10. Birnbaum J, Hellmann DB. Primary angiitis of the central nervous system. Arch Neurol 2009;66:704-9.

11. Elstner M, Linn J, Muller-Schunk S, et al. Reversible cerebral vasoconstriction syndrome: a complicated clinical course treated with intra-arterial application of nimodipine. Cephalalgia 2009;29:677-82.

12. Nowak DA, Rodiek SO, Henneken S, et al. Reversible segmental cerebral vasoconstriction (Call-Fleming syndrome): are calcium channel inhibitors a potential treatment option? Cephalalgia 2003;23:218-22.

13. Gerretsen P, Kern RZ. Reversible cerebral vasoconstriction syndrome or primary angiitis of the central nervous system? Can J Neurol Sci 2007;34:467-77.

14. Hajj-Ali RA, Furlan A, Abou-Chebel A, et al. Benign angiopathy of the central nervous system: cohort of 16 patients with clinical course and long-term followup. Arthritis Rheum 2002;47:662-9. 